\title{
THE IMPACT OF THE TAFT-HARTLEY ACT ON THE BUILDING AND CONSTRUCTION INDUSTRY
}

IN enacting the Taft-Hartley Act, ${ }^{1}$ Congress widened the scope of federal labor legislation. The old Wagner Act ${ }^{2}$ was directed only at management. Leaving unmolested labor's major weapons-the strike, the picket, and the closed shop-it empowered the National Labor Relations Board to enjoin employer unfair labor practices, including employer interference with labor's right to organize and bargain collectively and employer refusal to bargain with representatives selected by a majority of employees in appropriate units. ${ }^{3}$ In the Taft-Hartley Act, on the other hand, Congress for the first time provided for Board action against unfair labor practices on the part of a union or its agents. Among the prohibited practices are jurisdictional strikes and secondary boycotts. ${ }^{4}$ Taft-Hartley also gave the non-union worker more job security than he had under the Wagner Act, by prohibiting the closed shop and by permitting the union shop only when authorized by a majority vote of employees."

One of Taft-Hartley's most significant repercussions has been the NLRB's decision that the Act requires it to supervise the two and a half million workers ${ }^{6}$ in the American building and construction industry. Prior to 1947, when em-

1. The Taft-Hartley Act is title 1 of the Labor Management Relations Act of 1947, 61 STAT. 136 (1947), 29 U.S.C. \$§ 141 et seq. (Supp. 1947) (hereinafter cited as LMRA). For the legislative history of the Act, see NLRB, Legislative History of the Labor Managentent Relations Act (1948). Act).

2. 49 Stat. 449 (1935), 29 U.S.C. $\$ \$ 151-66$ (1946) (hereinafter cited as Wagner

3. Wagner Act $\S \S 7,8,10$. Under $\S 9(\mathrm{~b})$ the Board was empowered to designate the employer unit, craft unit, plant unit, or subdivision thereof as the appropriate unit for bargaining purposes.

4. LMRA $\S 8(\mathrm{~b})(4)$ (A) and (D). Other provisions of $\S 8(\mathrm{~b})$ pertinent to the construction industry are $8(\mathrm{~b})(2)$, making it an unfair labor practice for a union to secure the discharge of a non-union employee unless he is covered by a valid union shop agreement, and 8 (b) (6), making it an unfair labor practice to require pay for work not actually performed. Under $\$ 303$ of LMRA any person "injured in his business or property" by a violation of $\$ 8(b)(4)$ may sue the offending labor organization for damages. See Note, 59 Y AIE L. J. 575 (1950).

5. LMRA § 8(a) (3) prohibits the closed shop by implication, since it provides for no form of union security agreement other than the union shop. Section 9 (e) of the Act prescribes the procedure for union shop elections. See pags 690-91 infra.

6. U.S. Dept. of Labor, Construction, November, 1950, p. 13. Even in 1946 the construction industry employed more workers than mining, railroad transportation, or iron and steel manufacturing (the largest single manufacturing industry).

Industry:

No. of Employed Workers

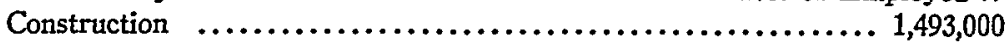

All mining $\ldots \ldots \ldots \ldots \ldots \ldots \ldots \ldots \ldots \ldots \ldots \ldots \ldots \ldots \ldots . \ldots . \ldots, 836,000$

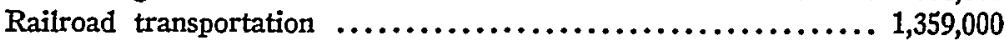

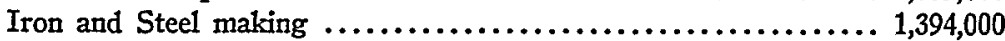

U.S. Dept. Labor, Monthly Labor Review, May, 1947, pp. 917-25. 
ployer practices alone were regulated, the NLRB refused to take jurisdiction in construction cases. ${ }^{7}$ It never made its reasons explicit. One reason may have been the Board's belief that many construction cases did not have a sufficient effect on interstate commerce. ${ }^{8}$ Another reason may have been the temporary and migratory nature of employment in the construction industry. ${ }^{9}$ This would have made the designation of appropriate bargaining units difficult; it might also have made cease and desist orders against employer unfair labor practices less effective because of completion of the project involved by the time the order issued. ${ }^{10}$ Finally, the Board may have felt that the craft unions in the construction industry were strong enough to take care of themselves, and that it should rather devote its time to fostering collective bargaining in mass production industries. ${ }^{11}$

When Taft-Hartley moved against employee practices by outlawing jurisdictional strikes, secondary boycotts, and the closed shop, however, the Labor Board resigned itself to a reversal of its hands-off policy. ${ }^{12}$ The specific practices named were thought to be prevalent in the construction industry. Implementation of the policy of the Act therefore seemed to require its application to that industry. ${ }^{13}$ The resultant policy switch presented the Board with several

7. Brown \& Root, 51 N.L.R.B. 820 (1943) (unfair labor practice charge) ; JohnsManville, 61 N.L.R.B. 1 (1945) (representation proceeding). But in one case the Board did exercise jurisdiction over construction workers regularly employed in a shipbuilding yard. Brown Shipbuildng Co., 57 N.L.R.B. 326 (1944).

8. In the Brown \& Root case, supra note 7, the Board refused to hear an unfair labor practice charge against a company constructing a naval air station in Texas, on the ground that the project was not in interstate commerce. But in the other pre-1947 construction case heard by the Board, it said that although the employer was clearly "within the purview of the Act," to hold a representation election in this instance "would not effectuate the policies of the Act." Johns-Manville, supra note 7.

9. See pp. 676-77 infra.

10. This has proved to be a problem under Taft-Hartley. In the first construction case which the Board took under that Act, Ozark Dam Constructors, 77 N.L.R.B. 1136 (1948), the construction crew had been dispersed before the Board issued its cease and desist order. See Report of the President, Proceedings of the Forty-Third Annual Convention of the Bunding and Construction Trades Departanest of the AFL, 129 (1950). Even under the summary procedures provided in $\$ 10$ (1) for obtaining temporary injunctions against secondary boycotts and jurisdictional strikes, an average of 41 days elapses between the filing of a secondary boycott charge in an NLRB regional office and the filing of a petition for a temporary injunction in the federal district court. Communication to the Yale Law JouRaAl from Winthrop A. Johns, Assistant General Counsel, NLRB, dated March 28, 1951, in Yale Law Library.

11. Workers in the construction industry were already highly organized; about $80 \%$ were members of the AFL building trades unions and $95 \%$ of those under union agreements worked in closed shops. Covington, Jurisdiction of the NLRB over the Building and Construction Industry, 28 N. C. L. Rev. 1, 2 (1949).

12. The Board turned about in spite of the fact that the jurisdictional clauses of Taft-Hartley did not change those of the Wagner Act. See LMRA $\$ \$$ (c)(1), 10(a), $2(6)$, and $2(7)$.

13. See, e.g., the statement of the Board in Wadsworth Building Co., 81 N.L.R.B. 802, 804 (1949): "[W]e believe, as we have on other occasions indicated, that it would 
major problems. ${ }^{14}$ Lacking the facilities for handling all complaints that might be brought before it, the Board had first to limit its jurisdiction within the industry. And beyond that, it faced the further tasks of applying the jurisdictional strike and secondary boycott provisions and conducting union shop elections in an industry peculiarly unsuited to such regulation. ${ }^{\mathbf{1 5}}$

\section{The Building and Construction Industry}

\section{Nature of the Industry ${ }^{16}$}

The building and construction industry is generally classified in six overlapping divisions: ${ }^{17}$ (1) heavy construction: dams, highways, bridges; (2) utilities construction: communications facilities, railroads, etc.; (3) industrial construction: new manufacturing plants and new units in existing plants; (4) commercial construction: office buildings and stores; (5) public and semipublic buildings : schools, hospitals, churches, government buildings; and (6) residential construction : apartments and houses. The construction of buildings, as opposed to roads, power lines, or bridges, is the backbone of the industry. Ordinarily residential building exceeds non-residential, and in years of pros-

effectuate the policies of this Act and accord with Congressional intent to assert jurisdiction over cases such as this, though involving the local construction industry, where interference therewith would have a substantial effect on interstate commerce. As legislative history shows, Congress, in enacting Section 8(b) (4) (A), as well as other provisions of the Act, intended, among other things, to reach certain practices prevailing in the construction industry which it deemed were detrimental to the public interest and which it expected to eliminate thereby." [Italics in original.] See also Plumbing Contractors Ass'n of Baltimore, 93 N.L.R.B. No. 177, n. 12 (1951) ; William G. Churches, 90 N.L.R.B. No. 66 (1950); Liddon White Truck Co., 76 N.L.R.B. 1181, 1184 n. 3 (1948) (statement of Board members Herzog and Murdock); speech by General Counsel Denham to the Associated General Contractors on Feb. 11, 1948, announcing that the Board would take jurisdiction in the industry. 26 LAB. REL. Rep. (Labor-Management) 166 (1948).

14. Section $8(\mathrm{~b})(6)$ of the LMRA, which strikes at featherbedding, has been applied to the construction industry without difficulty. See NLRB Ban on Featherbedding Takes First Bite at Construction Industry, 141 EngINeERING News-Record 3 (Aug. 12, 1948).

15. The construction industry has given the NLRB more trouble than any other in the three years since the passage of Taft-Hartley. Of the 79 cases in which General Counsel Denham, during his term of office, sought a 10(1) injunction against a union, over a third (27) involved building trades unions. Report of the President, ProceEdrags of the 43D Annual Convention of the Butrding and Construction Trades DepartMENT OF THE AFL, 128 (1950). Problems of applying the Act to the industry provoked much of the controversy between the Board and General Counsel Denham. See N. Y. Times, Jan. 13, 1950, p. 1, col. 2.

16. On the industry in general, see Haber, Industrias Relatrons in the Building Industry (1930); U.S. DEPT. OF LABOR, THE CONSTRUCtion INDUSTRY OF THE Unted States (1944); U.S. Dept. of Labor, Post-War Capacity and Characteristics of the Construction Industry (1944); 20tr Century Fund, American Housing (1944); Dunzop and Hili, The Wage Adjustument Board; Wartiale Stabilization IN THE BUILding and Construction Industry (1950).

17. See, e.g. Covington, supra note 11 , at 34 . 
perity it accounts for the major part of construction activity. ${ }^{18}$ The importance of residential construction, in which the single family house predominates, accounts for a preponderance of relatively small, short-term projects, ${ }^{19}$ widely scattered geographically.

\section{Employment Practices ${ }^{20}$}

Each project is a distinct entity for which a working force must be assembled at the site. It is generally located at some distance from the employer's preceding project and calls for a different number of workmen. As a structure progresses, the number of mechanics, helpers, and laborers for the various trades changes continually in response to the changing pattern of work. Considerable seasonal and cyclical variations in demand ${ }^{21}$ compel further flexibility in employment. Building employers generally reduce to a skeleton organization when necessary, retaining foremen and a few key workmen. They are prepared

18. In 1949 , for example, a total of $\$ 22,594,000,000$ was spent on the following types of construction:

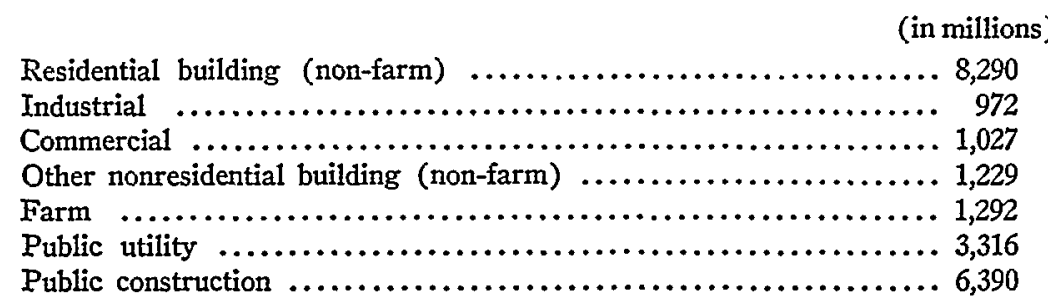

U.S. Dept. of Labor, Expenditures for New Construction 1915-1950, Table 1, p. 5 (1950).

19. While some unusually large industrial and commercial projects may provide steady employment for a competent craftsman over a period of a year or more, a 1936 study by the Bureau of Labor Statistics in ten cities indicated that for one-family frame dwellings the average period between commencement of excavation and completion of the structure was 88.8 days; for commercial buildings the average time was 88 days; and for public buildings it was 235.6 days. U.S. BurEau of Labor Statistics, Housing and Building Operations, Handeook of Labor Statrstics 219 (1936).

20. For a description of employment practices in general, see U.S. DEPT. of LABOR, Post War Capacity and Characteristics of the Construction Industry, 5 (1944).

21. In 1948, a year of high employment in the construction industry, the construction working force fluctuated from 1,792,000 workers in February, the low point of the building season, to 2,384,000 in August, the seasonal high-a spread of 592,000. No more than one out of every four building workers can be considered employed throughout the year. U.S. Dept. of Labor, Bureau of Labor Statistics Matertals on the ConstrucTION INDUSTRY, 7 (1949).

Cyclical fluctuations have been even more serious. In the Great Depression building employment fell over 58\% from its 1928 peak of 2.4 million men to the depression low of 1 million men in 1933. If full employment is maintained in the future, this type of fluctuation can, in spite of the natural 20-year building cycle, be made much less serious. For a survey of building employment, see U.S. DEPT. of LABOR, BUREAU of Labor STatistics Bulletin No. 984, Construction-1948 in Review 1. (1949). 
to expand within a very short time-a few days if necessary-by hiring workmen, foremen, and even superintendents as needed.

Employment in the construction industry can be distinguished from manufacturing employment on at least three grounds: construction employment is migratory, moving from one project to another, while manufacturing labor stays in the same place; construction jobs are of short duration; and most construction workers change employers as often as they change jobs, while factory workers have no occasion to switch bosses periodically. These conditions have led construction unions to demand from employers agreements that all employment will be made through union hiring halls. Most employers have acceded to this demand.22

\section{Labor Organizations ${ }^{23}$}

In their struggle for security the building unions have become well entrenched, tough, and conservative. ${ }^{24}$ Labor is organized along craft lines. The nineteen major building trades unions are members of the $A F$ of $\mathrm{L}$, whose supremacy in the field is virtually unchallenged. ${ }^{25}$ Over two million of the two and a half million workers in the industry are union members, ${ }^{26}$ and in some areas unionization is close to $95 \%$. The building unions, however, have had little success in highway construction, where a good deal of unskilled labor is used; in small housing developments where a speculative builder does the work with his own men rather than letting it out on contract; and in the South, where union security agreements are generally banned by state constitutions or statutes. $^{27}$

22. See page 689 inffra.

23. On labor organizations in the building industry, see generally HABER, INDUSTRIAI Recations in the Building Industry, chs. 10, 11 (1930). See also Mexers, The BUILding Workers-A Study of an Industrial Sub-Culture, unpublished doctoral thesis, University of Michigan (1945).

24. The sheltered nature of the building trades has been an important factor in the strength of unionism in the industry. Because the industry's product, with the unimportant exception of prefabricated units, cannot be transported, competition is highly localized. Also, the relative weakness of employers and employer-groups has been significant in strengthening the hand of most building unions.

25. For a list of the nineteen building unions, see Proceedings of the 43D ANrwal Convention of the Building and Construction Trades Departarent of the AFL (1950).

The International Association of Machinists seceded from the AF of $\mathrm{L}$ for a number of years, and during this period occasionally fought with the building trades unions over the allocation of jobs. In January 1951, however, the IAM reaffiliated with the AF of L, on condition that it be exempt from decisions of the Building Trades Department's Joint Board for the Settlement of Jurisdictional Disputes. See 27 LAB. REL. REP. (LaborManagement) 99 (1951).

26. Brief of the Building and Construction Trades Department of the AFL, Before the NLRB, In the Matter of the Building and Construction Trades Industry, p. 6 (1950).

27. E.g., Fla. Const., Dectaration of Rigrits $\$ 12$ (1944 amendment) ("The right of persons to work shall not be denied or abridged on account of membership or non- 
On the local level, the unions cooperate through building and construction trades councils, which are congregations of locals. The most powerful spokesman for each local is its business agent. He polices employers to maintain union conditions, settles grievances, protects his trade's jurisdiction, and preserves the working rules. He has the authority to call his local off any job, and is checked only by the necessity of consulting with the building trades council to secure the cooperation of the other trades in applying sanctions. Through him building unions can take coercive action with the speed required by the short-term nature of construction work. ${ }^{28}$

\section{Eimployers}

General contractors and special trade subcontractors are the two most important classes of employer. General contractors, who work on contract for owners, sublet most of the work out to special trade contractors, although they generally execute the work of one or more major trades themselves. Special trade subcontractors perform the work of a single trade or two or more related trades. Their work is usually done for the general contractor and occasionally directly for the owner. While some general contractors are large, ${ }^{29}$ the special trade subcontractors-the most numerous of the building industry's managerial groups-are almost uniformly small-scale operators. ${ }^{30}$

membership in any labor union"); 54 GA. CoDE ANN. $\$ 902$ (Supp. 1947) ("No individual shall be required as a condition of employment, or of continuance of employment, to be or remain a member or an affiliate of a labor organization").

28. See Haber, Industrial Retations in tHe Building Industry c. 10 (1930).

29. Large firms predominate in the heavy and commercial construction fields. In $1939,1 \%$ of the general contractors did more than a quarter of the dollar volume of the work performed by all building contractors. U.S. DEPT. OF LABOR, BUREAU of LABOR Statistics Materials on the Construction Industry 4 (1949).

30. Statistics on the number and size of the firms engaged in the industry in 1939 (the latest year for which figures are available) show an enormous number of small firms:

Number and size of contractors in the U.S. in 1939

\begin{tabular}{|c|c|c|}
\hline & $\begin{array}{l}\text { Number of } \\
\text { contractors }\end{array}$ & $\begin{array}{l}\text { Volume of } \\
\text { construction }\end{array}$ \\
\hline \multicolumn{3}{|l|}{111 contractors (including special trade subcontractors): } \\
\hline 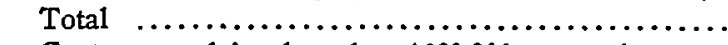 & 215,150 & $\$ 4,519,794,000$ \\
\hline Contractors doing less than $\$ 300,000$ ann. vol. & 213,170 & $\$ 2,921,990,000$ \\
\hline$\%$ of total $\ldots \ldots, \ldots, \ldots, \ldots, \ldots, \ldots, \ldots, \ldots$ & $99.1 \%$ & $64.6 \%$ \\
\hline Contractors doing less than $\$ 100,000$ ann. vol. ....... & 207,825 & $\$ 2,450,083,000$ \\
\hline 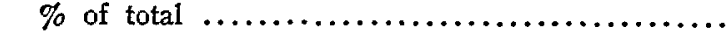 & $96.7 \%$ & $45.7 \%$ \\
\hline \multicolumn{3}{|l|}{ pecial trade subcontractors: } \\
\hline Total special trade contractors .... & 176,187 & $\$ 2,007,906,000$ \\
\hline $\begin{array}{l}\% \text { of total contractors } \ldots \ldots \ldots \ldots \ldots \ldots \ldots \ldots \ldots \\
\text { Special trade contractors doing less than } \$ 300,000\end{array}$ & $81.9 \%$ & \\
\hline ann. vol. $\ldots \ldots \ldots \ldots \ldots \ldots \ldots \ldots \ldots \ldots$ & 175,771 & $\$ 1,701,438,000$ \\
\hline$\%$ of total special trade contractor & $99.8 \%$ & $84.7 \%$ \\
\hline
\end{tabular}


The division of labor among contractors and subcontractors is an important feature of the industry. Subcontractors furnish most of the equipment, buy the bulk of the materials, and hire and direct most of the workmen, while the general contractor tends to become a coordinator of production. ${ }^{31}$ This contractorsubcontractor relationship makes the management on any project not a single employer but rather a group of employers united by physical proximity and by a common economic interest.

\section{Collective Bargaining}

Collective bargaining goes on at three levels. ${ }^{32}$ On an industry-wide level, the Building and Construction Trades Department of the AF of L, representing all nineteen building unions, negotiates with national employer associations ${ }^{33}$ and the federal Government. The agreement setting up the industry's Joint Board for the Settlement of Jurisdictional Disputes ${ }^{34}$ and the wage stabilization agreement of $1941^{\mathbf{3 5}}$ are products of such negotiation. In a craft-wide level the individual unions, in conjunction with groups of contractors and large national contracting firms, negotiate craft working rules. Finally, the building trades councils and union locals bargain with contractors and subcontractors on wages, hours, and working conditions. ${ }^{36}$

\begin{tabular}{|c|c|c|}
\hline 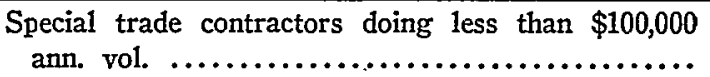 & 173 & $376,741,000$ \\
\hline$\%$ of total special trade & $98.6 \%$ & $68.6 \%$ \\
\hline
\end{tabular}

U.S. Dept. of Commerce, Bureau of the Census, Census of Business, 1939, Construction 1939, Vol. 4, pp. 6, 53 (1945).

31. See 20tr Century Fund, Amirrican Housing 99 (1944).

32. See Testimony of John Dunlop, Chairman of the industry's Joint Board for the Settlement of Jurisdictional Disputes, in Hearings before NLRB Hearing Officer Winkler, In the Matter of Plumbing Contractors Assoc. of Baltimore, Case No. 5-RC-94,95,96,700, Aug. 28-Nov. 13, 1950, p. 393 et seq.

33. Construction management is not organized as effectively as construction labor. The large number of contractors and the rapid turnover in building entrepreneurs partially explains this. General contractors have three national associations, the Associated General Contractors of America, the National Constructors Association and the Homebuilders Association. All have state and local branches. Specialty contractors have a number of national associations, such as the Painting and Decorating Contractors Association and the Master Plumbers Association, as well as a number of state-wide associations not affiliated with any national organization. Locally, in addition to the branches of the national associations, there are a number of city-wide employers associations such as the Building Trades Employers of New York or of Boston. See HABER, InDustriar ReLATIONS IN THE BuIlding INDUSTRX, c. 15 (1930). See also Brief of the Building and Construction Trades Department of the AFL, Before the NLRB, In the Matter of the Building and Construction Trades Industry, 6-7 (1949).

34. See pp. 683-84 infra.

35. For a history of the wage stabilization agreement, as well as other wartime dealings between the Building Trades Department and the federal Government, see Dusior and Hill, The Wage Adjustament Board (1950).

36. U.S. Dept. of Labor, Bureau of Labor Statistics Matertals on the ConSTRUCTION INDUSTRY, 15-18 (1949). 


\section{The BoARd Tares Jurisdiction}

The NLRB's problems in the building industry began when it decided to reverse its Wagner Act policy of total abstention. In some circumstances, the Board plunged ahead and accepted any case which it decided met the statutory requirement of affecting interstate commerce. ${ }^{37}$ Increasingly, however, it began to exercise restraint. ${ }^{38}$ Regardless of its statutory power, it rejected jurisdiction over operations small in themselves even though typical of large volumes of production. ${ }^{39}$ Rather the Board demanded that each dispute itself have a substantial effect on interstate commerce. ${ }^{40}$

In the "yardstick" decisions of October 1950, the Board took the further step of adopting specific rules of thumb. ${ }^{41}$ Under them the Board will exercise jurisdiction over: (1) any construction firm doing $\$ 50,000$ worth of business

37. For example, in Samuel Langer, 82 N.L.R.B. 1028 (1949), a secondary boycott case, the project where the alleged unfair labor practice occurred was the construction of a $\$ 15,200$ house. Langer, the non-union subcontractor whose presence on the job caused the dispute, had a $\$ 325$ contract. To find the requisite effect on interstate commerce, the Board was forced to rely on such factors as Langer's total annual purchases of supplies ( $\$ 8000$, of which $\$ 5000$ came from out of state), the general contractor's annual business $(\$ 60,000)$, and the amount of interstate business done by suppliers of each of these. For criticism of piling up of this type of data for purposes of finding jurisdiction, see Waller, J., dissenting, in Shore v. Building \& Construction Trades Council of Pittsburgh, 173 F. 2d 678 (3d Cir. 1949). Cf. Sperry v. Denver Building \& Construction Trades Council, 77 F. Supp. 321 (D. Col. 1948) (holding, on facts similar to the Langer case, that the Board had no jurisdiction).

Apparently the Board at first adopted the suggestion of General Counsel Denham that it should exercise jurisdiction over the building industry according to the type of unfair labor practice charged. Denham believed that if a union unfair labor practice such as a secondary boycott or a jurisdictional strike were alleged, the Board should exercise its authority even in situations where it would not take jurisdiction if an employer unfair labor practice were charged. Hearings before Subcommittee on Education and Labor and the Committee on Expenditures in the Executive Departments, 80th Cong., 2d Sess. 18 (1948). See Ira A. Watson, 80 N.L.R.B. 533, 534-5 (1948).

38. The first Taft-Hartley case involving an unfair labor practice occurring on a construction site in which the Board refused to take jurisdiction as a matter of discretion was Walter J. Mentzer, \$2 N.L.R.B. 389 (1949), a union shop case under $\$ 8$ (a) (3). Jurisdiction had previously been refused on policy grounds in several representation proceedings involving construction suppliers. E.g., Texas Construction Material Co., 80 N.L.R.B. 1248 (1948). See Walter J. Mentzer, supra at 391 n. 4.

39. See William G. Churches, 90 N.L.R.B. No. 66, 26 Lab. ReL. REF. Man. 1225, 1226 (1950).

40. $I d$. at 1226.

41. Federal Dairy Co., 91 N.L.R.B. No. 107 (1950). Dorn's House of Miracles, Inc., 91 N.L.R.B. No. 82 (1950); Hollow Tree Lumber Co., 91 N.I.R.B. No. 113 (1950); The Rutledge Paper Products, Inc., 91 N.L.R.B. No. 115 (1950); The Borden Co., 91 N.L.R.B. No. 109 (1950) ; WBSR, Inc., 91 N.L.R.B. No. 110 (1950); Local Transit Lines, 91 N.L.R.B. No. 96 (1950) ; Westport Moving and Storage Co., 91 N.L.R.B. No. 149 (1950). For a summary of the yardstick decisions, see 26 LAB. REL. REP. (LaborManagement) 393 (1950). 
annually ${ }^{42}$ in services for (a) an instrumentality or channel of interstate commerce, (b) a public utility or transit system, or (c) an establishment which produces or handles goods destined for out-of-state shipment or which performs services outside a state valued at over $\$ 25,000$ a year; (2) any construction firm having a flow of $\$ 500,000$ in materials direct from out-of-state or a flow of $\$ 1,000,000$ annually in materials originating out-of-state but purchased from local dealers; and (3) any construction firm whose work affects national defense. ${ }^{43}$

The Board has thus confined its jurisdiction over the construction industry to relatively large firms. Its decision was a sensible one. It can now attempt to apply the statute to areas of the industry where employment is of longer duration. Any remedies which it orders, if they are to be workable at all, have their best chance of succeeding in these areas. It is among the large construction firms, moreover, that NLRB remedies will do the most good; work stoppages there are most detrimental to the economy and to national defense.

\section{JuRISDictional Disputes}

The clearest manifestation in Taft-Hartley of Congressional intent to regulate the construction industry is its prohibition of strikes resulting from jurisdictional disputes. ${ }^{44}$ Jurisdictional disputes are quarrels between two unions, each claiming that its members have the right to perform a particular job. ${ }^{45}$ Such disputes are common in the construction industry, with its complex, constantly changing production methods and many craft unions. ${ }^{46}$

42. The Board has recently decided that for purposes of this test in a secondary boycott case, the relevant amount of annual business is that of the "primary" and "secondary" employers combined. Jamestown Builders Exchange, 93 N.L.R.B. No. 51 (1951).

43. On any construction project where an agency of the federal, state, or local government is the employer, the Taft-Hartley Act does not apply and the NLRB has no jurisdiction. These agencies are excluded from the definition of "employer" covered by the Act. LMRA § 2(2); Al J. Schneider, Inc., 87 N.L.R.B. 99 (1950).

44. Senator Taft stated that one of the purposes of the Act was to prevent jurisdictional disputes in the construction industry. 93 Cong. REC. A 3370 (1947). See Jurisdictional Disputes under the Taft Hartley Act, 1 LABOR L. J. 499 (1950).

45. See Haber, Industrial Relations in the Building Industry c. 6 (1930); Hyman \& Jaffe, Jurisdictional Disputes in Proceedings of tele New York University First ANNuAL Conference on Labor 442 (1948).

46. In 1946 there were reported to the Bureau of Labor Statistics 40 jurisdictional strikes in the construction industry involving 6 men or more and lasting longer than one day. This represented $11.4 \%$ of the total strikes in the industry and $12.9 \%$ of the total man days lost in all building strikes. U.S. Dept. of Labor, Construction; ANNUAL. Review 1950, Table 36 (1950). John Dunlop, chairman of the Joint Board for the Settlement of Jurisdictional Disputes, see pp. 683-84 infra, however, has reported that his Board handles as many as 30 to 40 jurisdictional dispute "situations" per month. Dunlop, Jurisdictional Disputes in Proceednas of the New York UNIvERstTY SECOND ANNuAL CONFERENCE ON LABOR 498 (1949). 
When a dispute cannot be settled quickly the employer must allocate the disputed work to one of the two unions. The result may be a jurisdictional strike by the other union. Normally such a strike will cause every craft on the project to walk out. ${ }^{47}$

Congress, determined to put an end to the jurisdictional strike, labeled it an unfair labor practice. Section $8(b)(4)(D)$ of the Act prohibits strikes to compel an employer to change his assignment of work unless the Board has authorized the change. And under Section $10(\mathrm{k})$ the NLRB is empowered to hear and determine disputes giving rise to $8(\mathrm{~b})(4)(D)$ violations after a ten-day waiting period during which parties may settle disputes themselves.

Section $10(\mathrm{k})$ gives the Board no clue as to what standards it should apply in determining disputes. Shifting for itself in several early cases, one of which involved the construction industry, the Board decided to accept employer work allocations as final in $10(\mathrm{k})$ determinations. ${ }^{48}$ Neither custom nor established union rule was considered.

Rubberstamping employer determinations of jurisdictional disputes in the building industry, however, is not a satisfactory solution. The employer is not necessarily a disinterested party caught helpless in the power politics of aggressive unionism; he may himself have touched off the dispute by violating work allocation customs in order to use those crafts who will accept lower hourly rates. ${ }^{49}$ Furthermore, decisions as important as those involved in jurisdictional disputes should, in so far as 8 (b) (4)(D) permits, be made by all groups affected by them, labor as well as management. ${ }^{50}$

Recognizing this, the NLRB General Counsel, Robert Denham, began in 1948 to encourage construction labor and management to work out their own procedures for settling jurisdictional problems. ${ }^{51}$ This encouragement, coupled with Taft-Hartley's threat of Board intervention, stimulated the Building Trades Department of the AF of $L^{52}$ and the National Association of Em-

47. For the case history of a jurisdictional dispute between the Carpenters and the Hodcarriers which tied up forty million dollars' worth of construction in northern New Jersey, see Northern New Jersey Jurisdictional Strikes in the AFL Building Trades, H.R. Hearings before the Special Subcommittee on Education and Labor, 80th Cong., 1st Sess., passim (1947).

48. Los Angeles Building \& Construction Trades Council, 83 N.L.R.B. 477 (1949) (construction); Irwin-Lyons Lumber Co., 82 N.L.R.B. 916 (1949) (lumbering); Juneau Spruce Corp., 82 N.L.R.B. 650 (1949) (lumbering).

49. See Dunlop, supra note 46 , at 477.

50. The allowance of a ten-day waiting period following the filing of an 8(b) (4) (D) charge suggests that Congress realized the desirability of joint settlement action by labor and management.

51. See the reference to a private plan for a settlement of jurisdictional disputes in Denham's speech of Feb. 11, 1948, to the Associated General Contractors of America, Inc., 21 LAB. Rez. Rep. 166 (1948). The day after this speech, the Associated General Contractors ratified the plan for the establishment of the Joint Board. See also note 54 infra.

52. On the Building Trades Department's prior efforts to find means of settling jurisdictional disputes in the industry, see Haber, Industrial ReLations In the BuildING INDUSTRY c. 7 (1930). 
ployers in the Construction Industry ${ }^{53}$ to set up a private Joint Board for the Settlement of Jurisdictional Disputes. ${ }^{54}$ The Joint Board, composed of an impartial chairman and eight members representing management and labor, is a trouble-shooting organization which tries to settle existing disputes on the basis of custom and inter-union agreements, ${ }^{55}$ and to prevent future disputes by formulating new nationwide rules as to work allocation. ${ }^{56}$ Unions

53. The National Association of Employers in the Construction Industry is a collective name for those employer associations signing the Joint Board Agreement. These associations consist of seven specialty contractors associations and the Associated General Contractors of America, Inc.

54. The Joint Board agreement became effective May 1, 1948, and was amended Oct. 1, 1949. Dunlop, supra note 46, at 477 (1949). See 21 LAB. REL. REP. (LaborManagement) 174 (1948) for the text of the original agreement, and AFL Burnding and Construction Trades Departament, Plan for Setrling Jurisdictional Disputes Nationally and Locally 3 (1950) (the so-called "Green Book") for the text of the amended agreement [hereinafter cited as Joint Board Agreement].

The Joint Board's processes are available not only to members of the signatory associations, but also to any contractor who employs unions affiliated with the AF of $\mathrm{L}$ Building Trades Department and who signs a stipulation that he is willing to be bound by the terms of the agreement establishing the Joint Board.

55. When a dispute is filed with the Joint Board, the Board first investigates the claims of the parties to determine whether a disposition of the dispute has been made by a previous decision of record or by a recorded agreement between the parties. If so, the Board determines which party is entitled to the work under the prior decision or agreement. If the Board finds that the dispute is not covered by a prior decision or agreement, it renders a "job decision", which is effective only on the particular job where the dispute occurred. Any such job decision may be appealed by any participating union or may be referred by the Joint Board itself to a "hearings panel" for review. Joint Board Agreement, Art. III, $\S 1$.

A separate hearings panel is appointed for each dispute. The panel consists of representatives of the affected unions and of participating employer associations, the chairman of the Joint Board, and two disinterested presidents of international unions selected by the chairman with the approval of the Joint Board. If the Board cannot reach a unanimous decision, the decision is made by the chairman and the two presidents. Id. Art. III, $\S 4$.

If a jurisdictional dispute occurs on a going project or over the method of starting a project, the contractor is to make a specific assignment of the disputed work. $\mathrm{He}$ is to make this decision on the following basis: (1) any relevant inter-union agreement recognized by the Joint Board or decision of record; (2) established local practice; or (3) the best decision the contractor himself can make after consultation with the parties. When a contractor has made a work assignment in this manner, the unions are pledged to remain at work and process any complaint in accordance with Joint Board procedures. If a protest against the employer's work assignment is filed with the Joint Board, the Board makes a job decision, which in turn is appealable to a hearings panel. JoINT BOARD, Procedural Rules and Regulations of the National Joint Board for the SettleMENT OF JuRisdictional Disputes (October 20, 1949).

All inter-tunion jurisdictional agreements recognized by the Joint Board are reprinted in "Green Book," supra note 54, at 11-124.

56. When a dispute is filed with the Joint Board with a specific request for a decision on a national basis, the chairman of the Joint Board calls a conference of the presidents of the unions involved in an effort to obtain a voluntary agreement between them. If the dispute is not settled by agreement within 10 days, a hearings panel is appointed to 
are pledged not to stop work pending a Joint Board decision, and both unions and employers are pledged to abide by that decision once made. ${ }^{57}$

The NLRB has cooperated fully with the Joint Board. Whenever a union which is a member of the AF of $\mathrm{L}$ Building Trades Department is charged with engaging in a jurisdictional strike, the NLRB notifies the Joint Board, which in turn seeks to settle the underlying dispute. This policy has proved to be amply justified. Possessing the experience, flexibility, and summary procedures necessary for effective mediation, the Joint Board has succeeded in settling every dispute referred to it by the NLRB. ${ }^{58}$

\section{SECONDARY Boycotts}

Section 8(b) (4) (A) of the Taft-Hartley Act provides that a union may not engage in or induce or encourage the employees of any employer to engage in a concerted refusal to work, where an object of the union's refusal or inducement is to make that employer cease doing business with any other person. Senator Taft stated that this section was designated to prohibit "secondary" pressure on neutral employers for the purpose of bringing ultimate pressure to bear on "primary" employers with whom unions are in dispute. ${ }^{59}$ In this way Congress hoped to check the spread of labor strife and keep disputes within their original boundaries. ${ }^{.0}$

Read literally, 8(b) (4)(A) would invalidate most picketing. ${ }^{61}$ While picketing is usually directed mainly at the picketed or "primary" employer's workers, it aims also to persuade the employees of other, or "secondary" employers, to refuse to cross the picket line. Thus an object of such picketing

hear and decide the dispute. Joint Board Agreement, Art. III, \& 2. Furthermore, the Joint Board may at its discretion direct the establishment of a hearings panel to establish a national decision in a jurisdictional issue. Jornt BoARd, Procedural RULES AND REguLations of the National Jotnt Board for the Settledient of Jurisdictionas. Disputes, 7 (1950).

57. Joint Board Agreement, Art. V, §1; Art. III, §7.

58. Testimony of John Dunlop, Hearings before NLRB Hearing Officer Winkler, In the Matter of the Plumbing Contractors Association of Baltimore, NLRB Case No. 5-RC-94,95,96,700, p. 467 (1950).

59. "This provision makes it unlawful to resort to a secondary boycott to injure the business of a third person who is wholly unconcerned in the disagreement between an employer and his employees." 93 Cong. REC. 4198 (April 29, 1947).

60. "Congress has now undertaken, in the exercise of its power under the Commerce Clause, art. $1, \S 8, \mathrm{cl} .3$, to prohibit altogether or sharply to curtail the use by labor organizations of certain economic weapons which they have heretofore freely employed. In an effort to narrow the area of industrial strife, and thus to safeguard the national interest in the free flow of commerce, it has in effect banned picketing when utilized to conscript in a given struggle the employees of an employer who is not himself a party to the dispute. Such we understand to be the purport of $\S 8(\mathrm{~b})(4)$ (A) of the Act." Printing Specialties and Paper Converters Union v. Le Baron, 171 F. 2d 331, 334 (9th Cir. 1948).

61. See Petro, Taft Hartley and the Secondary Boycott, 1 LABOR L. J. 835 (1950). 
is to induce the "secondary" employers to cease doing business with the "primary" employer.

The Board, however, has shied away from too literal a reading of 8(b) (4) (A). Picketing of a "primary" employer's place of business is permitted, regardless of its indirect effect on "secondary" employers. ${ }^{62}$ And where the "primary" and "secondary" employers are on the same premises. the Board, recognizing that there is no other way to conduct an effective picket, permits picketing of the entire premises as long as the placards clearly disclose that the dispute is with the "primary" employer. ${ }^{03}$ Here again, although an object of the picketing may be to induce the "secondary" employer to cease doing business with the picketed employer, the Board has stated that "incidental" effects on the "secondary" employer do not convert lawful "primary" action into lawful "secondary" action. ${ }^{64}$

In the construction industry, however, where picketing unions repeatedly condemn the entire job, proclaiming that their dispute is with the contractor for bringing onto the job a non-union subcontractor, ${ }^{65}$ the Board has decreed

62. International Rice Milling Co., 84 N.L.R.B. 360 (1949), enforcement denied, 183 F.2d 21 (5th Cir. 1950), cert. granted, 340 U.S. 902 (1950). See the Board's statement in Pure Oil Co., 84 N.L.R.B. 315, 318 (1949): "A strike, by its very nature, inconveniences those who customarily do business with the struck employer. Moreover, any accompanying picketing of the employer's premises is necessarily designed to induce and encourage third persons to cease doing business with the picketed employer. It does not follow, however, that such picketing is therefore proscribed by Section 8(b) (4) (A) of the Act." See also the Board's statement in Ryan Construction Corp., 85 N.L.R.B. 417,418 (1949): "V/hen picketing is wholly at the premises of the employer with whom the union is engaged in a labor dispute, it cannot be called 'secondary' even though, as is virtually always the case, an object of the picketing is to dissuade all persons from entering such premises for business reasons."

63. Moore Dry Dock Co., 92 N.L.R.B. No. 93 (1950) ("secondary" employer was a dock owner at whose dock the "primary" employer's ship was tied up); Ryan Construction Co., 85 N. L. R. B. 417 (1949) ("secondary" employer was a general contractor engaged in erecting an addition to the "primary" employer's plant); Schultz Refrigerated Service, 87 N.L.R.B. 502 (1949) ("secondary" employers were customers and consignees of "primary" employer, a trucking concern); Pure Oil Co., 84 N.L.R.B. 315 (1949) ("primary" and "secondary" employers used" same dock). In the Moore Dry Dock case, supra, the Board said that where the situs of a labor dispute is ambulatory, as in that case, picketing of the premises of a "secondary" employer is "primary" if it meets the following conditions: (1) the picketing is strictly limited to times when the situs of dispute is located on the secondary employer's premises; $(2)$ at the time of the picketing the primary employer is engaged in its normal business at the situs; (3) the picketing is limited to places reasonably close to the location of the situs; and (4) the picketing discloses clearly that the dispute is with the primary employer.

64. See especially the Board's statement in Schultz Refrigerated Service, 87 N.L.R.B. 502,508 (1949): "[W]e cannot regard the incidental interference with the business of other employers as sufficient to convert the Respondent's otherwise lawful primary picketing into unlawful secondary conduct."

65. Since August 22, 1947, the effective date of Taft-Hartley, a total of nearly 200 charges alleging violations of $8(\mathrm{~b})(4)$ (A) have been submitted to the General Counsel. Approximately $25 \%$ of these involved strikes or threats of strikes against construction 
that such picketing goes too far. Its purpose, says the Board, is largely to induce the contractor to sever relations with the subcontractor-an object forbidden by the Act. ${ }^{66}$

In three decisions ordering construction unions to cease and desist from such secondary picketing, the Board has been affirmed by two courts of appeals and reversed by a third. ${ }^{67}$ In International Brotherhood of Electrical Workers, Local 501 v. $N L R B,{ }^{68}$ a contractor erecting a house let out the carpentry work to a union subcontractor and the electrical work to a non-union subcontractor who hired two men to do the job. A local of the International Brotherhood of Electrical Workers ( $A F$ of $L$ ) picketed the site, proclaiming the entire project to be unfair and causing the union carpenters to strike. The NLRB ordered the picketing stopped, and the Court of Appeals for the Second Circuit affirmed. In Denver Building and Construction Trades Council v.

jobs because of the employment thereon of non-union subcontractors. Petition by NLRB for cert., Denver Building Trades Council v. NLRB, No. 393, Oct. Term 1950, p. 17.

66. The attacks on this activity in the major construction industry cases, discussed in the text infra, have been under 8(b) (4) (A). The decisions in those cases assume that the principal objectives of the picketing-to have the non-union men taken off the jobwere lawful, and that it was only the means used to obtain that objective-putting pressure directly on a "secondary" employer-that were unlawful. This assumption may not be valid. Section 8 (b) (2) of the Act makes it an unfair labor practice for a union or its agents "to cause or attempt to cause an employer to discriminate against an employee in violation of [Sec. 8(a) (3)]." Section 8(a) (3) in turn makes it an unfair labor practice for an employer to fire an employee on grounds of non-membership in a union unless the employee is covered by a valid union shop agreement, entered pursuant to the election procedure set up in $\$ 9(\mathrm{e})$. See discussion pp. 690-91 infra. There was no contention in any of the construction industry secondary boycott cases that any valid union shop agreement was in effect. The unions' attempts in those cases to have the non-union men fired from the jobs involved therefore probably constituted an unfair labor practice under $\S 8$ (b) (2), regardless of the presence or absence of a concurrent violation of $\$$ 8(b) (4) (A). See Fry Roofing Co., 89 N.L.R.B. No. 93 (1950) (pressure on employer to discharge six machinists held an 8 (b) (2) violation when union security agreement invalid because not properly executed by employer); National Maritime Union of America, 78 N.L.R.B. 971 (1948) (pressure on employer to enforce maritime hiring hall agreement held an $8(\mathrm{~b})$ (2) violation since union shop election requirement of $8(\mathrm{a})$ (3) not followed). See discussion of the union shop provisions, pp. 690-94 infra.

67. In a fourth case the Board issued a cease and desist order against a union picketing a contractor because he was using materials produced by a manufacturer with whom the union had a dispute. Wadsworth Building Co., 81 N.L.R.B. 802 (1949), enforcement granted, 184 F.2d 60 (10th Cir. 1950). The materials boycott is the only type of secondary boycott Congress spoke of in the construction industry when it was considering the Taft-Hartley Act. See Sen. Rep. No. 105, (80th Cong., 1st Sess.), p. 22 (1947). Such boycotts are outlawed under specific language in $8(\mathrm{~b})(4)(\mathrm{A})$, making it unlawful to pressure an employer to "cease using, selling, handling, transporting, or otherwise dealing in the products of any other producer, processor, or manufacturer ..." This is not involved in the three cases discussed in the text infra, except perhaps in the Watson case. See note 70 infra.

68. 181 F.2d 34 (2d Cir. 1950), enforcing Samuel Langer, 82 N.L.R.B. 1028 (1949), cert. granted, 340 U.S. 902 (1950). 
$N L R B,{ }^{69}$ on the other hand, the Court of Appeals for the District of Columbia reversed on substantially similar facts. In the third case, $N L R B$ v. Local 74, United Brotherhood of Carpenters and Joiners of America, $A F L,{ }^{70}$ the owner of a house being remodelled, despite warnings from the contractor, let out the installation of wall and floor coverings to a non-union supplier, who insisted on installing them himself. Local 74 of the United Brotherhood of Carpenters and Joiners of America had been seeking for some time to organize this supplier, and to that end had picketed his retail store. When the supplier accepted the remodelling job, the union also began to picket the house and induced the union men on the job to walk out. An NLRB cease and desist order was affirmed by the Sixth Circuit Court of Appeals. All three cases are now before the Supreme Court. ${ }^{71}$

Apparently the only way of rationalizing all the Board's decisions under $8(\mathrm{~b})(4)(\mathrm{A})$ is to assume that the Board is reading that section as if it said "the main object" rather than "an object." This test avoids application of 8 (b) (4) (A) to strike down labor activity which prevents employees of trucking concerns, shippers, and the like from entering picketed premises. It also effectively distinguishes the three construction industry cases from those cases arising in other industries where picketing directed against a primary employer takes place on premises occupied also by a secondary employer. There incidental pressure necessarily falls on the secondary employer. The "main object" of the picketing in the three construction cases, on the other hand,

69. 186 F.2d 326 (D.C. Cir. 1950), denying enforcemeilt to Gould and Preisner, 82 N.L.R.B. 1195 (1949), cert. granted, 340 U.S. 902 (1950). In the Denver case, the union argued that the decision of a district court denying Board counsel a 10 (e) injunction at the opening stage of the Board's proceeding, Sperry v. Denver Building Trades Council, 77 F. Supp. 321 (D.C. Col. 1948), on the ground that interstate commerce was not affected, was res judicata in the subsequent unfair labor practice proceeding. In denying this contention, the Court of Appeals for the District of Columbia spoke as follows: "Where the application of the judicial doctrine res judicata would be inconsistent with method devised by Congress the doctrine will not be enforced by the courts. . . . It is for this reason we hold against the contention of petitioners, and not because of lack of any of the elements which usually make out a case for the application of res jutdicata." 186 F.2d 326, 332 (D.C. Cir. 1950).

70. 181 F.2d 126 (6th Cir. 1950), enforcing Ira A. Watson, 80 N.L.R.B. 533 (1948), cert. granted, 340 U.S. 902 (1950). The Watson case contains elements which might be used to distinguish it from the Electrical Workers and Denver cases: (1) The union on strike had an alternative place to apply pressure against the subcontractor-namely, at his retail store-which is not the case in strikes against most subcontractors; (2) The general contractor had no choice in the selection of the non-union subcontractor, since the owner insisted on materials which only the Watson store could supply; (3) The Board speaks of a boycott of the installation of materials, analogizing it to the secondary boycott of building suppliers specifically stigmatized by Congress, see note 67 , infra.

71. For a report of the oral argument before the Supreme Court in these cases, see Taft Act's Boycott Ban before the Supreme Court 27 LAB. REL. REP. 183 (1951). For a discussion of questions which the cases present under the Commerce Clause, see Covington, supra note 11 . 
was to induce the so-called "secondary" employer-the general contractorto cease dealing with the "primary" employer-the subcontractor-so long as the subcontractor continued to use non-union labor.

This test makes sense of a statute which literally outlaws all picketing. As applied by the NLRB to the construction industry, however, it may sterilize organized construction labor's only effective economic weapon. ${ }^{72}$ That industry differs from almost all others in that a union cannot organize an employer by appealing to his workers alone. With employers numerous, employment of short duration, and individual craft units small on any one project, unions have traditionally been forced to rely on the cooperation of all workers on a job in order to bring pressure on any particular employer. Thus where one subcontractor refuses to hire union men, the spurned union pickets the entire project to induce the union employees of other subcontractors on the job to walk out. This in turn is designed to compel the general contractor to sever relations with the non-union subcontractor.

The difficulty in applying the main object test to the construction industry lies not in that test itself. If $8(\mathrm{~b})(4)$ (A) is to mean anything, it must mean that picketing whose main object is to force a "secondary" employer to cease dealing with a non-union "primary" employer is unlawful. The difficulty rather is in the Board's assumption that the general contractor must be considered a "secondary" employer. If construction industry crafts generally are to be left with any effective right to bring pressure for organization, this assumption must be re-examined.

Basic to the idea that "secondary boycotts" are undesirable extensions of a labor dispute is the premise that they are directed against an employer who is neutral to the dispute, i.e., who has not caused it and is at least only incidentally interested in its outcome. Phrased another way, this means that a boycott is not "secondary" when it is aimed at the person or organization who adopts the labor policies complained of. For example, if Plant $A$ refuses to maintain the wage levels demanded by a union which represents a majority of employees in the plant, that union has a legitimate quarrel with A's management. Section $8(b)(4)(A)$ prevents this quarrel from being extended to Plant $\mathrm{B}$, a buyer from or seller to $\mathrm{A}$. The union has a quarrel with Plant $\mathrm{B}$; it objects to Plant B's policy of dealing with A when A is refusing the union's demands. But this quarrel is unconnected with B's own labor policies. The main purpose in picketing $B$ would be to compel him to cease buying goods from or selling goods to $A$, the original target of the dispute. This $S(b)(4)(A)$ forbids. ${ }^{73}$

72. See Judge Clark's recognition of this in his dissent in the Electrical Workers case, supra note 68, at 40: "For Giorgi's [the contractor] giving Langer [the non-union subcontractor] the contract is the very heart of the matter; and if the union is barred from reaching Giorgi at all, its traditional weapons are blunted and perhaps destroyed."

73. For a similar hypothetical designed to illustrate the effect of 8 (b) (4) (A), see Sen Rep. No. 105, 80th Cong., 1st Sess. 22 (1947). 
The general contractor in the construction industry is in a significantly different position. Unlike $B$, in the example above, the general contractor's own labor policies are the reason his place of work is being picketed. For he has brought onto the job a non-union subcontractor. This, as Judge Clark pointed out in his dissent in the Electrical Workers case, is the immediate cause of the dispute. ${ }^{74}$ For purposes of $8(\mathrm{~b})(4)$ (A) all the men working on the job should be considered the general contractor's employees; he should not be allowed to insulate himself from the effects of having non-union men work side by side with union men simply because the custom and structure of the industry places a subcontractor between him and direct employment of the non-union men. ${ }^{75}$ In other words, the test should be whether the direct employer of the non-union man (the subcontractor) is sufficiently closely connected both geographically and economically with the indirect employer (the general contractor) so that the labor policies of the one may be attributed to the other. The contractor-subcontractor relationship in the construction industry should be held to satisfy this test.

The general contractor, however, should be regarded as the employer of a subcontractor's employees only for purposes of that job where the two contractors are working together. Therefore, although a construction union trying to organize any subcontractor on a project should have the right to picket the entire project, it should not be permitted to extend its activity to other sites on which the general contractor is working. Since the purpose of the picketing is to organize a particular job, the geographical boundaries of that job should mark the confines of the dispute. ${ }^{76}$

74. "In a practical sense the immediate cause of trouble for the union is Giorgi [the contractor] in bringing onto this job-which he initiates and controls-a non-union subcontractor. Giorgi does it presumably for the natural reason that he thus obtains a low rate." 181 F. 2d 34, 41 (2d Cir. 1950).

75. "We think in fact the picketing must be considered as against both Doose and Lintner [the contractor] and Gould and Preisner [the subcontractor]-inseparably; and that its object was to bring the job to a standstill until the non-union electricians were replaced. The job was said to be 'unfair'. The contractor cannot separate itself from the conditions there so as to make the action by the Council against it secondary; nor can the subcontractor." Fahy J., in Denver Building and Construction Trades Union v. NLRB, 186 F. 2d 326, 337 (D.C. Cir. 1950).

76. Judge Fahy seemed to have a similar limitation in mind in his opinion in the Denver case. He stated: "Petitioners [the union] did not say to Doose and Lintner [the contractor], in effect, 'We will not work for you if you do business with Gould and Preisner [the subcontractor].' They said, in effect, 'We will not work with non-union men, and therefore we will not work for you at the place to which you bring Gould and Preisner with non-union men.' We think this action of petitioners was of a primary character even if petitioners envisaged it might result in a cessation of work on the particular job by Gould and Preisner." Id. at 337. 


\section{Union Shop ELECTIONS}

The third Taft-Hartley target in the construction industry was the closed shop. ${ }^{77}$ The union hiring hall is a commonplace in the industry. And since the hiring halls are typically available only to union men, ${ }^{78}$ the industry has long operated under what is in effect a closed shop. This arrangement was not disturbed by the Wagner Act, which expressly sanctioned closed shop agreements. ${ }^{79}$

Section 8(a) (3) of the new Act bans the closed shop. ${ }^{80}$ Instead, it permits unions to contract with employers for a union shop-i.e., an agreement requiring as a condition of employment membership in the union within thitty days after hiring-provided certain requirements are met. The union must first file with the Board a petition alleging that at least $30 \%$ of the employees in an appropriate unit desire a union ship; ${ }^{81}$ the union shop must then be

77. In reporting out $S$. 1126, which later became the Taft-Hartley Act, the Senate Committee on Labor and Public Welfare, after condemning the union hiring hall, stated: "[T]o a large extent in the construction industry union hiring halls now provide the only method of securing employment." SEN. REP. No. 105, 80th Cong., 1st Sess. 6 (1947).

78. Mellot, Hiring Halls in the Building Trades Industry, 11 U. PITrs. L. REv. 103 (1949). See also Sen. Rep. No. 99, 81st Cong., 1st Sess. 16, 17 (1949).

79. Wagner Act $\$ 8(3)$. The Wagner Act established only one prerequisite to a closed shop agreement: the union negotiating it was required to be the majority representative of the employees in the unit covered by the agreement. This requirement has been retained by the Taft-Hartley Act for the union shop agreement. IMRA $\$ 8$ (a) (3). But if a union can satisfy Taft-Hartley's more stringent union shop election requirement, see note 82 infra, the question of majority representation will be academic.

80. The only union security agreement permitted by LMRA $\S 8(a)(3)$ is the union shop agreement.

The legality of the industry's union hiring hall system was never tested prior to the passage of the Taft-Hartley Act in 1947, since the Board had consistently refused to take jurisdiction over the industry. After 1947, however, the Board had occasion to review union security agreements, the validity of which had to be tested under Wagner Act provisions because the agreements had been entered into prior to the effective date of TaftHartley. In two cases, Daniel Hamm Drayage Co., 84 N.L.R.B. 458 (1949), and Atkinson-Jones Construction Co., 90 N.L.R.B. No. 27, 26 LAB. REI. REF. MAN. 1164 (1950), the firing or refusal to hire employees pursuant to a union shop agreement was held to constitute an unfair labor practice under Wagner Act $\S 8(3)$, on the ground that the unions could not show they were the representatives of the majority of the employees at the time the agreements were made. Such proof would, of course, have been impossible. The Board was taking the jobs involved as the appropriate bargaining units. The agreements were concluded before the hiring began. Hence there were no employees to represent at the time the agreements were made. The Hamm and Atkinson-Jones cases therefore would seem to make the union hiring hall system in the construction industry open to attack under Taft-Fartley $\$ 8(a)(3)$ even if the union shop election requirements of that section were amended to exclude the construction industry. See note 101 infra. Endorsement of broader, multi-employer bargaining units, however, would probably obviate this difficulty. See pp. 691-93 infra.

81. LMRA $\$ 9(e)(1)$. 
approved by a majority of the employees eligible to vote. ${ }^{82} \mathrm{~A}$ union shop authorization, once obtained, may be rescinded in the same manner-by a $30 \%$ petition and a secret ballot against the union shop. ${ }^{83}$

The Board, just as in the case of representation proceedings, is given the job of determining what units are appropriate for bargaining purposes. ${ }^{84}$ In most industries the Board designates a unit no broader than a single employer. $^{85}$ To designate the members of a craft working for a single empioyer or working on a single project as the appropriate unit in the construction industry, however, creates special problems. For one thing, almost any decision based on such a unit, even if rendered with unprecedented speed, becomes obsolete as employees shift to other employers or the composition of the working force on a project changes. Furthermore, taking a unit no broader than the single employer or project makes it impossible to conclude union security agreements in advance and hence makes it very difficult for contractors to submit bids. In order to make bids, contractors need to know before a job starts what their labor costs will be. Construction unions, however, refuse to agree on wages and hours until assured that all hiring will be done through the union hiring hall. Finally, the sheer number of employers and crafts in the construction industry makes the holding of elections a tremendous administrative task. A single project may involve as many as 35 unions and 10 employers. ${ }^{86}$

General Counsel Denham, in an effort to mitigate these problems, proposed that union shop elections be held in various "employer areas." 87 Denham planned to take about 560 established building trades council jurisdictions as

82. LMRA $\$ 8(a)(3)$. The majority required in a union shop election differs from the majority required in a representation election. In the latter situation, it is simply a majority of those employees actually voting, not those eligible to vote. S. W. Evans \& Son, 75 N.L.R.B. 811 (1948).

83. LMRA $\$ 9(e)(2)$.

84. The Act apparently contemplates that the same "appropriate bargaining unit" be used for representation elections and union shop elections.

85. In some cases the Board has held appropriate a multi-employer unit. E. g., Shipowners' Ass'n. of the Pacific Coast, 7 N.L.R.B. 1002 (1938). It justified its action under the statute, which provides that the broadest permissible unit is the "employer unit," see note 3 supra, by pointing to the definition of "employer" in $\$ 2(2)$. Id. at 1024 . The latter section in the Wagner Act stated that the term "employer" includes any person "acting in the interest of an employer, directly or indirectly." The Board felt that the five employer associations which were designated an appropriate unit in that case were "acting in the interest of" the individual employers. The same reasoning is available under the Taft-Hartley Act, which defines an "employer" to include any person "acting as an agent of an employer." LMRA \$2(2).

The Board has further held that an employer association may be the appropriate unit even when the association does not have the power to bind its members in advance-i.c., where the final contracts are executed independently by each employer after the association has done the actual bargaining. Balaban \& Katz, 87 N.L.R.B. 1071 (1949).

86. Sen. Rep. No. 99, 81st Cong., 1st Sess. 17 (1949).

87. Denham's speech of Feb. 11, 1948, to the Associated General Contractors sets out his election scheme in full. 21 LAB. REL. REP. (Labor-Management) 166 (1948). 
a practical approximation of employer group areas, and to add from 50 to 150 areas of his own where no councils existed. To identify individual voters, Denham's office was to conduct a nation-wide survey to obtain from every general and special contractor a list of the workers on his payrolls in each craft group. The data thus acquired was to be entered on permanent uniform cards. Upon completion of this survey, each area was to have simultaneous craft elections for the 10 to 20 unions doing business in that area. Denham hoped that with full cooperation from management and labor this plan would make feasible the holding of union shop elections throughout the industry. ${ }^{88}$

Denham's first step was to conduct a "pilot" union shop election among highway construction workers in western Pennsylvania. The outcome was overwhelmingly in favor of the union shop. ${ }^{89}$ Although Denham's election crews took three months to lay the groundwork for it, the election presented relatively minor problems; only five unions, some 2700 employees, and about 100 employers, mostly represented by a single association, were involved. Nevertheless, even with full cooperation from both labor and management, the cost of the election came to about sixteen dollars per vote..$^{90}$

Then, in two further test cases, the obstacle of non-cooperation was added to that of cost, and it became clear that the Denham plan was administratively impracticable..$^{91}$ In Philadelphia, a pilot election was aborted when a union refused to accept the proposed geographical boundaries of the employer area. In Detroit, the refusal of the powerful Home Builders Association to cooperate meant that the essential payroll records were unobtainable, and compilation of a voting list impossible. ${ }^{92}$ Denham, discouraged, attempted to postpone the election problem by putting all requests for elections in the building industry into cold storage.93 Some time later he suggested to the Board that the union shop authorization requirement be overlooked until a means of

88. Denham realized that the task of holding elections would be monumental. He estimated it would call for polling over 2,000,000 employees, represented by 19 different national unions and working for over 300,000 contractors and subcontractors. He expected that the total cost would be from $\$ 1$ to $\$ 1.5$ million. 22 LAB. Rex. REP. (Labor-Management) 334 (1948).

89. In the voting, 2483 out of the 2709 employees voted, $89.2 \%$ in favor of a union shop and $10.8 \%$ against, much as the unions and management had predicted. Brief of the Building and Construction Trades Department of the AFL before the NLRB, In the Matter of the Construction Industry, p. 34 (1949). This meant that of the employees eligible to vote, about $82.7 \%$ voted in favor of the union shop.

90. Sen. Rep. No. 99, 81st Cong., 1st Sess. 17 (1949).

91. Ibid. On December 19,1949, Denham admitted to the Board that experience in trial elections had shown his election scheme to be "administratively impractical," 25 LAB. REL. REP. (Labor-Management) 107 (1949).

92. For an account of the Philadelphia and Detroit election attempts, see Brief of the Building and Construction Trades Department, supra, note 89, at 32-5.

93. Denham shelved his election scheme on Oct. 12, 1948. See Breakdozen in Union Shop Polls in Building Trades, 22 LAB. REt. REP. (Labor-Management) 334 (1948). By December, 1949, there were 167 pending petitions which Denham had refused to process. Brief of the Building and Construction Trades Department, supra note 89, at 29. 
holding elections in the industry be found. ${ }^{94}$ The Board refused, ${ }^{95}$ and Denham resigned before he could clarify his policy further..$^{90}$

Although the Denham plan never really got underway, the theory behind it has apparently gained some headway in the Board. In two recent decisions, one a union shop and the other a representation case, the Board endorsed election schemes based on a single craft, multi-employer bargaining unit. ${ }^{07}$ Both cases involved single employers' associations apparently representing all the employers in the area who dealt with the craft union filing the petition. The problem of independent employers, not members of the association, was therefore not presented. Since the language of the statute has been interpreted to permit designation of a multi-employer bargaining unit only when the employers are somehow linked together, this problem may seriously disrupt the election process in some circumstances. ${ }^{98}$

94. May NLRB Relax Rules for Building Trades?, 25 LAB. REL. REP. (LaborManagement) 107 (1949). Denham proposed specifically: (1) that until adequate administrative procedures were set up, the Board should presume that the union-shop requirements had been met in the construction industry, even though no election had been held; (2) that the Board should consider the 30-day provisions of 8 (a) (3) met so long as the employee involved had been in a unit covered by a union security contract for 30 days, regardless of whether he had worked for one or more employers during that period; and (3) that the Board should continue to handle in normal fashion any unfair labor practice charges not dependent on the election requirement provision.

95. The Board announced that it appreciated Denham's efforts to find a solution to the union shop provisions, but stated that it could not "join in so much of the General Counsel's proposed policy as would tend to vary or nullify the plain language of the present statute, no matter how tempting practical considerations might make that course" 26 LAB. REL. REP. (Labor-Management) 128 (1950).

96. Denham resigned and was replaced by George J. Bott on Sept. 28, 1950.

97. Plumbing Contractors Ass'n. of Baltimore, 93 N.L.R.B. No. 177 (1951) (representation case); Plumbing and Heating Contractors Ass'n. of Olean, N. Y., 93 N.L.R.B. No. 176 (1951) (union shop election). In each case the bargaining unit sought by the petitioning union and concurred in by the affected employers consisted of all plumbers working for members of the local plumbers' association. There were 22 individual employers in the Baltimore association and 5 in the Olean association.

98. Although the Board has endorsed multi-employer units in non-construction cases, see note 85 supra, as well as in the cases cited in note 97 supra, it is not clear how far it will extend its reading of "employer unit" in $\$ 9(\mathrm{~b})$ to include a group of employers not bound together in some sort of an association. Its rationale in previous cases might prevent it from going very far. See discussion, note 85 supra. Cf., however, George Carlton \& Co., 54 N.L.R.B. 222 (1943) (representation case; endorsement of a bargaining unit comprising an association and three independent employers, on a showing that the independents closely followed the association's policies). There are no indications that non-associated employers openly following divergent policies could be treated as one "employer," and it is not even sure that a court would agree with the Board's interpretation in the Carlton case of the statutory language of $\$ 9(\mathrm{~b})$. This means that a suffciently uncooperative group of employers could sabotage a multi-employer unit election scheme simply by dissolving their association. It also means that one or more individual contractors, if big enough so that most of the work in an area were done for them, could make an election meaningless simply by withdrawing from the association and refusing to be bound by the election which subsequently takes place. In either case, the failure of 
The Board has apparently abandoned completely Denham's industry-wide election plan, and is planning to sit back and wait for cases to come to it. It has, however, announced that it will not refuse to take construction industry unfair labor practice cases simply because they involve union shop problems.99 And it has apparently decided to hear election petitions. ${ }^{100}$ While the cases coming up may not be numerous, ${ }^{101}$ this policy creates a potential administrative burden for a futile purpose-any election held will simply ratify a foregone conclusion, and any unfair labor practice finding merely penalize a union for not having followed a useless and difficult formality. To avoid such results, the Act should be amended to exempt the building and construction industry from the union shop authorization requirements. ${ }^{102}$

the election would bear no relation to the desires of the majority of the employees in the area.

Section 9(b) also permits, as one of the alternatives to an "employer unit," designation of a "craft unit" as an appropriate bargaining unit. Literally, this would seem to permit making one of the construction crafts the basis of a bargaining unit, and holding an election for that craft within a specified area regardless of the number of individual employers affected. The section has not been so interpreted thus far. See Ass'n. of Motion Picture Producers, Inc., 88 N.L.R.B. 520 (1950) (area-wide bargaining unit proposed by carpenters and set erectors held not appropriate where no history of joint bargaining by the various employers' associations involved, even though all drew on a common labor pool).

99. See the Board's statement in 26 LAB. REx. REP. (Labor-Management) 129 (1950):

"Assuming that we are to continue to exercise jurisdiction over the building construction industry, and yet that some of the union shop provisions of the Act cannot be made to work there, it is our duty to report that fact to the Congress, rather than to change the law ourselves by administrative exemption of a single industry.

"Of course, so long as the General Counsel thinks it fairest and best to exercise his exclusive discretion by declining to issue complaints of unfair labor practice if employees are discharged pursuant to an unauthorized union-shop contract, the Board could not, if it would, conduct a hearing or find a violation of law. If and when, however, any such case reaches the Board members for decision, we will have no choice but to enforce the law as written."

100. See the Baltimore and Olean cases, supra note 97.

101. It seems doubtful that unfair labor practice charges will ever constitute a serious problem under 8(a) (3). In'Fry Roofing Co., 89 N.L.R.B. No. 93 (1950), the discharge of six machinists was held to be an unfair labor practice on the ground that the union security agreement involved was not properly executed by the employer. This case, the Hamm case, and Atkinson-Jones, see note 80 supra, are the only construction industry cases that have been brought under 8 (a) (3) by employees who have been discriminated against. The disputes leading up to all three arose when the IAM split off from the AF of $L$. The complaining workers were IAM members who were either denied work, or fired, under union security agreements made by the employer with the $A F$ of $L$ union. With IAM now back in the fold, see note 25 supra, a recurrence of $8(a)(3)$ complaints seems unlikely. For discussion of the possibility of an $8(\mathrm{~b})$ (2) charge against a union for causing an employer to violate 8 (a) (3), however, see note 66 supra.

102. Such an amendment would not impugn Taft-Hartley's aims. The purpose of the union shop election requirement is to insure against union security agreements entered into against the will of the majority of workers to be affected. The high degree of unionization in, and the whole tradition of, the construction industry makes this particular type 


\section{ConcLusion}

The National Labor Relations Act, as amended by Taft-Hartley, is not designed to meet the conditions of the construction industry. In applying legislation designed for factory employment to building, the NLRB has been faced with the choice of amending the Act administratively to allow for the peculiarities of the industry or enforcing it literally and leaving the problem of adjustment to Congress. The Board has done the latter-notably in promising to enforce the union shop election requirement and in stigmatizing union pressure on contractors hiring non-union sub-contractors.

On the other hand, the actual effect of Taft-Hartley in the industry has been slight. ${ }^{103}$ At most, the establishment of the Joint Board for the Settlement of Jurisdictional Disputes may be credited to it. ${ }^{104}$ Unions have continued, of necessity, to apply so-called "secondary" pressure at the local level, the Board's interpretation of $8(\mathrm{~b})$ (4) (A) notwithstanding. Indeed, even should the Supreme Court affirm the Board, such pressure will continue and in most cases go unmolested. The non-union subcontractor who calls forth "secondary" pressure is most frequently found on small projects. And the Board, under its recent "yardstick" decisions, will probably refuse to take jurisdiction over those projects.

Nevertheless, the Act's shortcomings should be remedied. The union shop authorization requirement should be abandoned for the industry. And the Supreme Court should exempt from $8(\mathrm{~b})(4)$ (A) traditional construction union pressure against general contractors who bring onto a job non-union sub-contractors. ${ }^{105}$ If the Court does not, Congress should, assuming it wishes to insure the right of construction labor to organize and bargain collectively.

of protection unnecessary. See page 677 supra. The superfluity of union shop elections was conceded during the 1949 move for repeal of the Taft-Hartley Act. See SEN. REP. No. 99, 81st Cong., Ist Sess. 16-17 (1949) (majority report); $i d$. at 38 (minority report).

103. A major reason for this is the fact that enforcement of the Act's unfair labor practice provisions depends on private persons' bringing charges under them. LMRA Sec. 10(b) ; Rules AND Regulations of the NLRB, Series 5, $\$ 203.9$ to 203.12. In the building industry, the practice of most management and labor groups seems to be to ignore the Act and continue the traditional practices of the industry. See note 101 supra; Hearings before the Joint Committee on Labor Management Relations, 80th Cong., $2 \mathrm{~d}$ Sess., Part 1, p. 120 (1948).

104. Taft-Hartley, however, was not solely responsible. The building unions and contractors associations were considering a voluntary joint plan early in 1947 before Congress started debating the Taft-Hartley Act. And in testimony before the Joint Committee on Labor Management Relations, Richard Gray, President of the AF of L Building Trades Department, said that negotiations for the establishment of the Joint Board predated the Taft-Hartley Act by two years. Hearings before the Joint Conmittec on Labor Management Relations, 80th Cong., 2d Sess. 118 (1948).

105. After this issue had gone to press the Supreme Court refused to do this. Instead it affirmed the Electrical Workers and Watson cases and reversed the Denver case. The Court also reversed the International Rice Milling case, supra note 62. 19 U.S.L. WEEK $4357-70$ (U.S. June 5, 1951). 